\title{
Determinants of consumers' purchasing intentions toward organic foods: A study in Ho Chi Minh City, Vietnam
}

\author{
Ha Thi Phuong Minh ${ }^{1 *}$, Duong Trong Nhan ${ }^{2}$
}

${ }^{1}$ Saigon Technology University, Vietnam

${ }^{2}$ Ho Chi Minh City Open University, Vietnam

*Corresponding author: haphuongminh08@gmail.com

\begin{tabular}{ll}
\hline \multicolumn{1}{c}{ ARTICLE INFO } & \multicolumn{1}{c}{ ABSTRACT } \\
\hline $\begin{array}{l}\text { DOI:10.46223/HCMCOUJS. } \\
\text { econ.en.9.1.178.2019 }\end{array}$ & $\begin{array}{l}\text { Applying the Theory of Planned Behavior (TPB) this } \\
\text { research investigates the factors explaining the purchasing } \\
\text { intention of organic food among consumers living in Ho Chi Minh } \\
\text { City, Vietnam, and identifies factors influencing their attitude } \\
\text { toward buying organic foods. The quantitative method with }\end{array}$ \\
& $\begin{array}{l}\text { Exploratory Factor Analysis (EFA), Confirmatory Factor } \\
\text { Analysis (CFA) and Structural Equation Model (SEM) from 370 }\end{array}$ \\
Received: July $3^{\text {rd }}, 2018$ & $\begin{array}{l}\text { valid questionnaires were used. The study found that health } \\
\text { consciousness \& food safety, environmental consciousness \& } \\
\text { Revised: August 10 }\end{array}$ \\
Accepted: March $4^{\text {th }}, 2019$ & $\begin{array}{l}\text { consumer knowledge, and availability product impact } \\
\text { significantly on consumer attitude toward buying organic food; } \\
\text { customer attitude, subjective norm, and perceived behavioral } \\
\text { control have a significant influence on their purchasing intention. } \\
\text { The findings of the study provide useful information to marketers } \\
\text { for increasing organic food consumption in Vietnam. The findings } \\
\text { imply that marketing activity should focus on the change of } \\
\text { people's attitude and lifestyles to increase the consumption of } \\
\text { organic food in Ho Chi Minh City. } \\
\text { Consumers' attitude, Organic } \\
\text { food, Purchase intention, } \\
\text { Theory of Planned Behavior }\end{array}$
\end{tabular}

\section{Introduction}

In recent years, much negative news about unsafe food in the media has directly or indirectly affected the health of consumers. Typically, thousands of fish were killed because of discharges of poisonous chemicals from Vedan, Formosa; especially, coffee was mixed with battery's powder in Dak Nong Province, etc. It says that food safety has become a major concern for consumers, and it is always a state of alarm in major cities. In fact, the worse the quality of food is getting, the more difficult consumers are to choose the right source of nutritious food while maintaining their health. The term "Organic Food" with advantages of food safety and hygiene and nutrition have responded to consumers' demand and organic food seems to become an indispensable trend of smart consumers in the future.

Organic food is not too strange to consumers in developed countries. In 2015 there were almost 2.4 million organic producers worldwide, global retail sales of organic food reached 75,709 million euros increasing by $10 \%$ compared to the previous years, and per capita consumption was 10.3 euros. North America and Europe generated the highest organic product 
sales (90\% of organic food sales) with per capita consumption of 108 euros and 36.4 euros respectively. Global share of organic food sales and per capita consumption in Asia, Latin America, Oceania and Africa remained small and slight (Willer \& Lernoud, 2017).

In Vietnam, consuming organic food has been an emerging trend. The market of organic food in Vietnam has grown slightly because Organic Food Industry in Vietnam was obstructed by consumers' awareness, producers' distribution and government's organic certification (Takayama, 2017). It seems that the expensive prices of organic food have affected the level of organic food consumption. Prices of organic and safe vegetables are as twice or triple as prices of non-certified vegetables (Tung Anh, 2018) or prices of organic rice are five times more than the prices of conventional rice (Vietnamnet, 2015).

This research aims to investigate the determinants of HCM City consumers' intention to purchase organic food. The findings of the study provide useful information for marketers to increase organic food consumption in Vietnam.

\section{Literature reviews}

Organic food consumption has attracted researchers' attention in the world. Table 1 summarizes recent studies related to the topics.

\section{Table 1}

Summary of recent studies of organic food consumption

\begin{tabular}{|l|l|}
\hline \multicolumn{1}{|c|}{ Titles } & \multicolumn{1}{|c|}{ Authors } \\
\hline $\begin{array}{l}\text { An exploration in the theory of planned behavior: A case of } \\
\text { organic food in Vietnam. }\end{array}$ & Tran and Tran (2016) \\
\hline $\begin{array}{l}\text { Consumer attitudes and purchase intentions in relation to organic } \\
\text { food in Taiwan: Moderating effects of food-related personality traits. }\end{array}$ & Chen (2007) \\
\hline $\begin{array}{l}\text { Attitude toward organic food among Taiwanese as related to } \\
\text { health consciousness, environmental attitudes, and the } \\
\text { mediating effects of healthy lifestyle. }\end{array}$ & Chen (2009) \\
\hline $\begin{array}{l}\text { Factors that influence the purchase of organic food. A study of } \\
\text { consumer behavior in the UK. }\end{array}$ & $\begin{array}{l}\text { Dickieson, Arkus, and } \\
\text { Wiertz (2009) }\end{array}$ \\
\hline $\begin{array}{l}\text { Consumers' attitude and intention towards organic food } \\
\text { purchase: An extension of theory of planned behavior in } \\
\text { gender perspective. }\end{array}$ & Irianto (2015) \\
\hline $\begin{array}{l}\text { Consumers' buying behavior toward organic foods: } \\
\text { Evidence from the emerging market. }\end{array}$ & Hossain and Lim (2016) \\
\hline $\begin{array}{l}\text { Consumers' purchase intention of shoes: Theory of planned } \\
\text { behavior and desired attributes. }\end{array}$ & Wang (2014) \\
\hline
\end{tabular}




\begin{tabular}{|l|l|}
\hline \multicolumn{1}{|c|}{ Titles } & \multicolumn{1}{|c|}{ Authors } \\
\hline $\begin{array}{l}\text { Determinants of willingness to purchase organic food: An } \\
\text { exploratory study using structural equation modeling. }\end{array}$ & $\begin{array}{l}\text { Voon, Ngui, and Agrawal } \\
(2011)\end{array}$ \\
\hline $\begin{array}{l}\text { Consumers' attitude and intention to purchase organic foods } \\
\text { in Cambodia. }\end{array}$ & $\begin{array}{l}\text { Kouya, Sangkumchaliang, } \\
\text { and Adittoc (2016) }\end{array}$ \\
\hline $\begin{array}{l}\text { The factors on influence consumer behavior on the purchase of } \\
\text { organic food products. }\end{array}$ & Leong and Ng (2014) \\
\hline $\begin{array}{l}\text { Attitudes towards organic foods among Swedish consumers. } \\
\text { Hursti, Aberg, and Sjödén } \\
(2001)\end{array}$ \\
\hline $\begin{array}{l}\text { Factors driving Thai consumers' intention to purchase } \\
\text { organic foods. }\end{array}$ & $\begin{array}{l}\text { Pomsanam, Napompech, } \\
\text { and Suwanmaneepong (2014) }\end{array}$ \\
\hline $\begin{array}{l}\text { Consumers' perception and attitudes of organic food products } \\
\text { in northern Sangkumchaliang Thailand. }\end{array}$ & $\begin{array}{l}\text { Sangkumchaliang and Huang } \\
\text { (2012) }\end{array}$ \\
\hline Consumer perceptions towards organic food. & Shafie and Rennie (2012) \\
\hline Consumers' purchase intention or organic food in China. & Yin, Wu, Du, and Chen (2010) \\
\hline
\end{tabular}

Source: The researcher's data analysis

From literature reviews, there is little research on determinants of Vietnamese consumers' intention to purchase organic food, so we conduct this research in order to bring about useful implications for marketing organic food in Vietnam. The next section presents the meanings of all research concepts used in this research.

\section{Organic food}

According to the Agriculture Marketing Service of the United States Department of Agriculture (USDA), organic is a labeling term that indicates the food or other agricultural products have been produced through approved methods (2017). These methods integrate cultural, biological, and mechanical practices that foster cycling of resources, promote ecological balance, and conserve biodiversity. Organic food is produced without using most conventional pesticides, fertilizers made with synthetic ingredients or sewage sludge. The food is not processed by irradiation, industrial solvents or chemical food stabilizers and excludes any additional ingredients (Albala \& Allen, 2007).

\section{Purchasing intention}

Consumers' buying decision is very complex (Keller, 2001). Purchasing intention is a significant factor used to predict purchasing process (Ghosh, 1990), impacted by price, quality perception and value perception (Zeithaml, 1988). Consumer behavior would be changed by physiological motivation (Kim, Lee, \& Lee, 2001). Purchase intention can be studied by applying the Theory of Planned Behavior (TPB) suggested by Ajzen (1991). 


\section{Consumer Attitude}

Ajzen (1991) defined that attitude toward behavior indicated the degree to which a person has a favorable or unfavorable evaluation or appraisal of the behavior in question. Attitude developed through experiences might change when a new experience is obtained (Ajzen, 2001; Chen, 2007). The more positive the attitude is regarding a behavior, the stronger the individual's intention is to perform the behavior under consideration (Tarkiainen \& Sundqvist, as cited in Tran \& Tran, 2016). Attitude toward a certain behavior is based on the expectations and beliefs of the consequences because of behavior (Ajzen, 1991; Tarkiainen \& Sundqvist; Chen, as cited in Tran \& Tran, 2016).

\section{Subjective norm}

Subjective norm is a social factor which refers to the perceived social pressure to perform or not to perform the behavior. Subjective norms are a function of one's beliefs that are formed by others in one's life (Ajzen \& Fishbein, 1980). Also, subjective norms are the impacts of external factors on customer intention (Miller et al., as cited in Tran \& Tran, 2016). Subjective norm is one of the factors which predict consumer behavior, when an individual's actions influence another consumer behavior (Sheeran \& Taylor, as cited in Tran \& Tran, 2016).

\section{Perceived behavioral control}

Perceived behavioral control refers to the perceived ease or difficulty of performing behavior and is assumed to reflect experience as well as anticipated impediments and obstacles (Ajzen, 1991). Furthermore, perceived behavioral control is related to the level of control that a person perceived over consumer behavior (Chen, 2007; Kang, Hahn, Fortin, Hyun, \& Eom, 2006). Therefore, an individual who perceives a higher percentage of personal control would have stronger behavioral intention to buy a product. In general, there are many factors such as time, money, and skills which are known as explaining factors of perceived behavioral control (Ajzen, 1991).

\section{Consumer attitude}

\section{Health consciousness}

Health consciousness is considered to influence consumers' attitude in which people are aware of their healthiness in their diet and lifestyles (Yang, Al-Shaaban, \& Nguyen, 2014). Health consciousness is the foremost potential theme to target consumption. If consumers believe that organic food is good for their health, they would have a positive attitude toward organic food (Kouya et al., 2016). Generally, one of the major reasons for buying organic food is health consciousness and environmental preservation (Wandel \& Bugge; Vindigni et al., as cited in Irianto, 2015).

\section{Environmental consciousness}

Although the environmental concern is not a main or strong reason as health, increasing concern about protecting the environment is still a motive for using organic food (Radman, 2005). According to Leong and $\mathrm{Ng}$ (2014), are willing to purchase and consume more organic products when they became more environmental concern. The other idea showed that 
consumers who cared for more environmentally friendly related issues had a positive attitude towards organic food (Vermeir \& Verbeke, 2006).

Consumer knowledge

In Brucks's research (1985), consumer knowledge was classified into three types via subjective knowledge, objective knowledge and prior experience. Subjective knowledge shows consumers' perception, objective knowledge referred to real knowledge and previous experience that consumers have ever accumulated before. When consumers have more knowledge about organic food, their attitude becomes more positive in consuming organic food (Stobbelaar et al., 2007). On the other hand, consumers with a higher level of organic product knowledge are more willing to buy organic food and experiencing buying organic food and they would have a more positive attitude toward organic food than non-experience consumers (Roddy, Cowan, \& Hutchinson, 1996).

Food safety

Food safety concerns not only consumers' health but also natural farming methods and clean and non-chemical food. According to Lobo, Mascitelli, and Chen (2014), only $10 \%$ of consumers has concerned Genetically Modified Organisms (GMOs) while more than 50\% of others concerned about pesticide residue on the food they purchase. Anxiety of food insecticide contamination and genetically modified organisms is an important factor in promoting consumers toward buying organic food (Dickieson et al., 2009). Consumers also care about product composition (Kavaliauske \& Ubartaite, 2014), production methods, labeling, and insufficient information of organic products which could impact consumers' decision to buy products (Roitner-Schobesberger, Darnhofer, Somsook, \& Vogl, 2008).

According to Cadilhon (2009), consumers in Asia and the Pacific region are increasingly worried about their food safety. The concerns have been appearing because of recurrent food crises with pesticide residues on fresh produce, food contamination by chemicals in dairy and seafood products, and unregulated use of additives in processed foods, etc. As a result, organic food has been perceived as safer by consumers because of free chemical, the guaranty of low chemical residues than products from conventional farming.

\section{Availability products}

Nowadays, to meet the increasing need of organic foods, they are available to consumers in most of the ordinary supermarkets, and big retailers, and more easily to approach consumers (Dettmann \& Dimitri, 2009). In addition, the availability of products was the main element for retailers to put up for their sales (Blackwell, Miniard, \& Engel, 2001).

\section{Research hypotheses development}

\section{Food safety, Health consciousness and Consumer attitude}

Roddy et al. (1996) indicated that consumers who were more anxious about food safety had a positive attitude to organic food. The result of Tarkiainen and Sundqvist's study (as cited in Irianto, 2015) mentioned that health consciousness positively affected the attitude to buy organic food. Chen (as cited in Irianto, 2015) showed that there was a strong significant 
relationship between health consciousness and attitude toward organic food purchasing. It indicated that consumer's health consciousness encouraged the consumer to have a positive attitude to buy organic food. It occurred because organic food was perceived as healthier, safer and environmentally friendly than the conventional one (Irianto, 2015). Based on the discussion above, the first hypothesis is proposed as follows:

Hla,b: Food safety \& Health consciousness has a significant effect on consumers' attitude toward organic food purchasing intention

\section{Consumer knowledge, Environmental consciousness and Consumer attitude}

According to Padel and Foster (2005), consumer knowledge has a positive influence on consumers' attitude toward organic food. Moreover, Chen (2009) indicated that environmental awareness encourages consumers to have a positive attitude towards using organic food. Environmental consciousness affects the consumer attitude to purchase organic food positively (Vindigni; Tarkiainen \& Sundqvist; Chen; Kim \& Chung, as cited in Irianto, 2015). Consumer knowledge and their attitude has a correlation relationship (Stobbelaar et al., 2007). Consumers' environmental consciousness encourages consumers to have a positive attitude towards organic food purchase because organic food cultivation is conducted by taking the environmental aspects into account involving the use of organic compost and manure fertilizer, and natural pest and disease control leading to minimizing the negative effects on the environment (Irianto, 2015). Based on the discussion above, hypotheses H2 was proposed as below:

H2: Consumer knowledge \& Environmental consciousness has a significant effect on consumers' attitude toward organic food purchasing intention

\section{Availability products and Consumer attitude}

Davies, Titterington, and Cochrane (1995), and Shafie and Rennei (2012) confirmed that the availability of organic food is one of the factors to encourage consumers toward purchasing organic food. Food availability could give an impulse to consumer's purchasing toward organic food (Shafie \& Rennie, 2012). Lack of organic food in supermarkets or shops is a negative factor influencing consumers to buy organic food (Brown, 2003; Davies et al., 1995; Hossain \& Lim, 2016). Thus, the third hypothesis was proposed as follows:

H3: Availability product has a significant effect on consumers' attitude toward organic food purchasing intention

\section{Consumer attitude and purchase intention}

The theory of planned behavior indicated that attitude is one of the three basic factors used to determine purchase intention because purchasing attitude has a direct effect on consumers' behavior (Ajzen, 1991). According to Landell (1992) (as cited in Tran \& Tran, 2016), attitudes toward a product indicate the feelings that customer focuses on things they are interested. Consumers who have a favorable attitude toward a product would be more inclined to buy the product. Therefore, attitudes toward organic food are related to purchase intention; otherwise, they would not buy the product (Moye \& Kincade, 1999, as cited in Tran \& Tran, 2016). Tarkiainen and Sundqvist (2005) conducted that consumers' attitude toward 
organic food and their purchasing intention have a significant positive relationship. The fourth hypothesis was suggested as below

H4: Consumer attitude has a positive influence on consumers' purchasing intentions toward organic food

\section{Subjective norm and purchasing intention}

Subjective norm is described as the subject influencing one's behavior (Ajzen, 1991). Subjective norm and intention of purchasing organic food have an important relationship (Chang, 1988). In addition, Bamberg (2003), and Kalafatis, Pollard, East, and Tsogas (1999) indicated that subjective norm has a strong relationship with purchase intention for green products. Besides, individuals' intention to consume organic food is likely to be strengthened if they believe that their loved ones expect them to do so, or they wish to be identified with other individuals who are consuming organic food (Chen, 2007). Previous studies also stated that subjective norm is one of the factors used to predict consumer behavior, as an individual's actions influencing on another consumer behavior (Sheeran \& Taylor, as cited in Tran \& Tran, 2016). Subjective norm has a positive attitude toward purchasing behavior to gain consumers' buying intention (Wang, 2014). Based on the discussion above, the fifth hypothesis was generated:

H5: Subjective norm has a positive influence on consumers' purchase intention toward organic food

\section{Perceived behavioral control and purchase intention}

Perceived behavioral control is related to the level of control that a person perceives over consumer behavior (Chen, 2007; Kang et al., 2006). An individual who perceived a higher level of personal control would have a stronger intention to buy organic food. As they have belief in their great resources, their perception of control is high, and their behavioral intentions increase (Ajzen, 1991). Perceived behavioral control is also related to the level of control that a person perceives over purchasing behavior (Chen, 2007; Kang et al., 2006). Based on the reviews from previous literature, the sixth hypothesis was made:

H6: Perceived behavioral control has a significant influence on consumers' purchase intention toward organic food

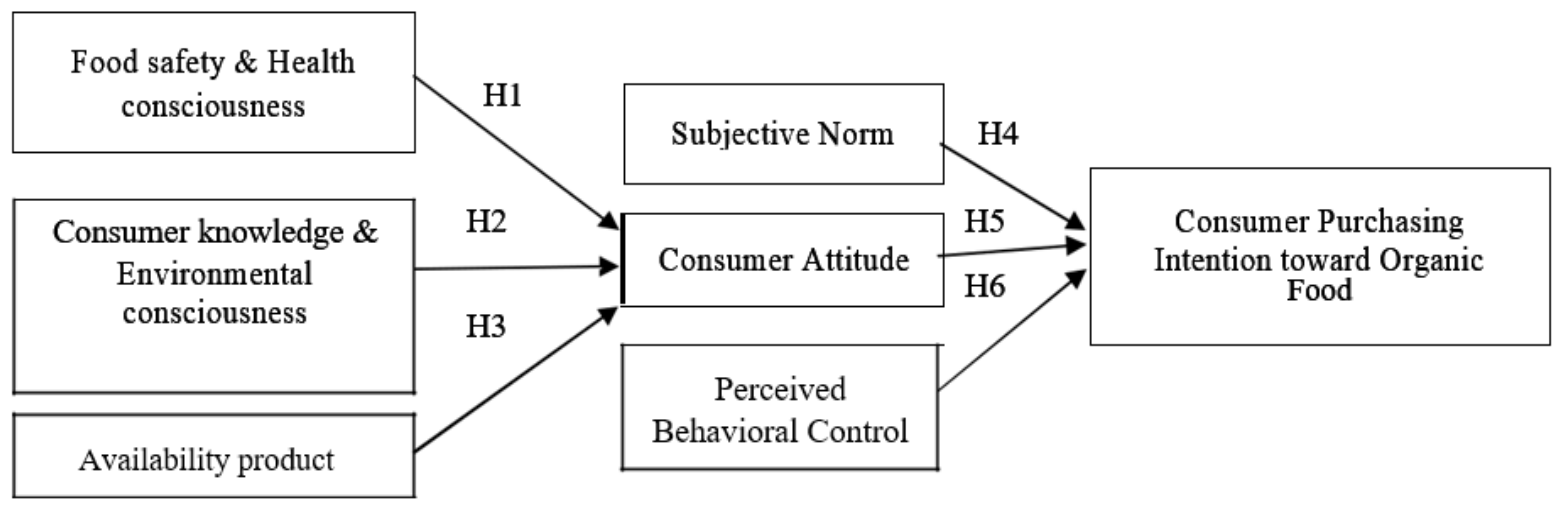

Figure 1. Proposed research model 


\section{Research method}

The quantitative research method was applied as the main method for this study. The questionnaire was designed to gather primary data from a sample population of consumers in Ho Chi Minh City. The questionnaire consists of 28 items using five-point Likert- scale that were divided into constructs including Health consciousness (4 items), Environmental consciousness (3 items), Consumer knowledge (3 items), Food safety (3 items), Availability products (3 items), Consumer Attitude (3 items), Subjective norm (3 items), Perceived behavioral control (3 items), Purchase intention (3 items). Questionnaires were distributed, and 376 responses were collected with 370 valid questionnaires and analyzed by SPSS and AMOS software.

\section{Data Analysis}

Exploratory factor analysis (EFA) was undertaken to identify and confirm the factors under each construct; items with loadings smaller than 0.4 were dropped from further analysis. Likewise, four items of old factors that load on more than one factor was assigned to the factor where it achieves the highest factor loading to form two new factors with Cronbach's Alpha was higher than 0.8. The Kaiser-Meyer-Olkin (KMO) measure of sampling adequacy had a value of 0.899 while Bartlett's test of Sphericity was significant ( $\mathrm{Sig}=.000$ ) indicating that the data is suitable for factor analysis. Seven factors with eight values greater than one are extracted and no items are dropped due to low factor loadings. The results of CFA show that Chi-square statistic is 395.066; the degree of freedom (df) is 287; the percentage of Chi-Square/df is 1.425 less than 2, and p-value is 0.000. The CFI is 0.984, the GFI (0.925) and TLI (0.982) are higher than 0.9 ; RMSEA is 0.034 . These evidence prove the validity and reliability of measurements. Besides, the standardized regression weights are greater than 0.5 indicating that the variables were observed to achieve convergence value. Moreover, the composite reliability (CR) of each factor is higher than 0.7, and variance extracted (AVE) of each factor is higher than 0.5, both of CR and AVE are satisfied with suggested criteria of 0.7 and 0.5 (Bagozzi \& Yi, 1988); thus, no items of the factors in the model needs to be removed. Structure Equation Model (SEM) was used to test the hypothesis. The result of the SEM model shows in Figure 1. 


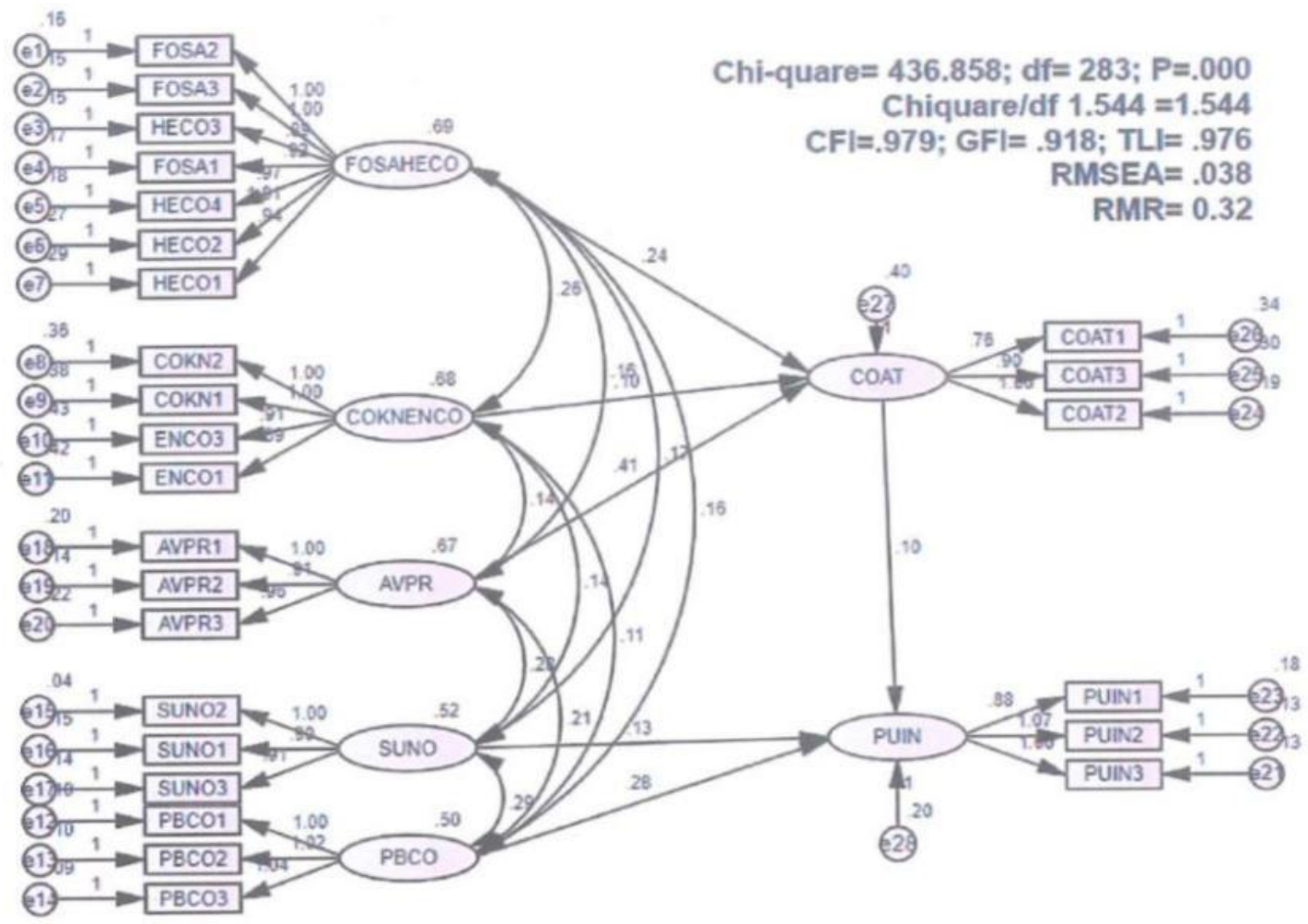

Figure 2. SEM result

Chi-square is 436.858; degree of freedom is ( $\mathrm{df}$ ) is 283 with p-value $=0.000$. Chisquare/df is 1.544 less than 3 . The other indexes as CFI $=0.979, \mathrm{GFI}=0.918$, and TLI $=0.976$ are greater than 0.9, and RMSEA is equal to 0.038, lower than 0.08. As a result, all indexes are satisfied with suggested criteria. The SEM regression weights allow supporting the five hypotheses (H1, H3, H4, H5 and H6) at the level of significance lower than 5\% while $10 \%$ for hypothesis $\mathrm{H} 2(\mathrm{sig}=0.075)$ in Table 2 .

\section{Table 2}

SEM Regression Weights

\begin{tabular}{|l|c|c|c|c|}
\hline & Estimate & S.E. & C.R. & P \\
\hline $\begin{array}{l}\text { COAT<--- FOSAHECO } \\
\text { (Consumer attitude <--- Food safety \& Health consciousness) }\end{array}$ & .241 & .052 & 4.670 & $* * *$ \\
\hline $\begin{array}{l}\text { COAT<--- COKNENCO } \\
\text { (Consumer attitude <--- Consumer knowledge \& Environmental } \\
\text { consciousness) }\end{array}$ & .096 & 0.54 & 1.780 & .075 \\
\hline $\begin{array}{l}\text { COAT<--- AVPR } \\
\text { (Consumer attitude <--- Availability products) }\end{array}$ & .410 & .052 & 7.810 & $* * *$ \\
\hline $\begin{array}{l}\text { PUIN<--- PBCO } \\
\text { (Purchase intention <--- Perceived behavioral control) }\end{array}$ & .285 & .050 & 5.742 & $* * *$ \\
\hline
\end{tabular}




\begin{tabular}{|l|c|c|c|c|}
\hline & Estimate & S.E. & C.R. & P \\
\hline $\begin{array}{l}\text { PUIN<--- SUNO } \\
\text { (Purchase intention <--- Subjective norm) }\end{array}$ & .130 & .048 & 2.699 & .007 \\
\hline $\begin{array}{l}\text { PUIN<--- COAT } \\
\text { (Purchase intention <--- Consumer Attitude) }\end{array}$ & .104 & .038 & 2.716 & .007 \\
\hline
\end{tabular}

Source: The researcher's data analysis

\section{Table 3}

The result of hypothesis testing

\begin{tabular}{|l|l|}
\hline $\begin{array}{l}\text { H1: Food safety \& Health consciousness has a significant effect on consumers ' } \\
\text { attitude toward organic food purchasing intention. }\end{array}$ & Accepted \\
\hline $\begin{array}{l}\text { H2: Consumer knowledge \& Environmental consciousness has a significant effect } \\
\text { on consumers' attitude toward organic food purchasing intention. }\end{array}$ & Accepted \\
\hline $\begin{array}{l}\text { H3: An Availability product has a significant effect on consumers' attitude } \\
\text { toward organic food purchasing intention. }\end{array}$ & Accepted \\
\hline $\begin{array}{l}\text { H4: Consumer attitude has positive influence on consumers' purchasing intention } \\
\text { toward organic food. }\end{array}$ & Accepted \\
\hline $\begin{array}{l}\text { H5: Subjective norm has positive influence on consumers' purchase intention } \\
\text { toward organic food. }\end{array}$ & Accepted \\
\hline $\begin{array}{l}\text { H6: Perceived behavioral control has significant influence on consumers' } \\
\text { purchase intention toward organic food. }\end{array}$ & Accepted \\
\hline
\end{tabular}

Source: Data analysis result of the research

\section{Conclusion}

Health Consciousness and food safety have a significant influence on consumer attitude toward organic food purchasing intention. This result is like the findings of Yang et al. (2014) and Roddy et al. (1996). Availability products also have an influence on consumers' attitude toward organic food as the result of Davies et al. (1995). This study indicated environmental consciousness and consumer knowledge influence consumer attitude toward organic food; the result is the same with the finding of Vermeir and Verbeke (2006), Chen (2009), Stobbelaar et al. (2007). Consumer attitude has a positive influence on consumers' purchasing intentions toward organic food. This result is in line with Ajzen (1991). Subjective norm has a significant effect on consumers' intention to buy organic food (Tarkiainen \& Sundqvist, 2005). Perceived behavioral control has a significant influence on consumers' intentions toward organic food. This finding is in line with Armitage and Conner (2011).

In summary, the study found three factors that influence significantly positively on consumer attitude toward organic food purchasing intention of HCM City consumers. They are Food safety \& Health consciousness, Consumer knowledge \& Environmental consciousness, and product Availability. The study also confirmed three factors (consumer attitude, subjective 
norm, and perceived behavioral control) influencing purchase intention toward organic food. The findings imply that marketing activity should focus on people's lifestyles aspects to promote the consumption of organic food in Ho Chi Minh City. The main weakness of the study is using a convenience sampling technique with a small sample of 370 respondents living in Ho Chi Minh City, so the generalization of research findings is limited. Further research should survey people living in other big cities of Vietnam such as Hanoi, Da Nang, Nha Trang, Can Tho, etc. to investigate attitude toward organic food and purchase intention of urban residents.

\section{References}

Ajzen, I. (1991). The theory of planned behavior. Organizational behavior and human decision processes, 50(2), 179-211. doi:10.1016/0749-5978(91)90020-T

Ajzen, I. (2001). Nature and operations of attitudes. Annual Review of Psychology, 52(1), 2758. doi:10.1146/annurev.psych.52.1.27

Ajzen, I. B., \& Fishbein, M. (1980). Understanding attitudes and predicting social behavior. Upper Saddle River, NJ: Prentice-Hall.

Albala, K., \& Allen, G. (2007). The business of food: Encyclopedia of the food and drink industries. Westport, CT: Greenwood.

Alvensleben, R. V. (1998). Ecological aspects of food demand: The case of organic food in Germany. Institute for Agricultural Economics, University of Kiel, 4, 68-79.

Armitage, C. J., \& Conner, M. (2001). Efficacy of the theory of the planned behavior: A metaanalytic review. British Journal of Social Psychology, 40(4), 471-499. doi:10.1348/014466601164939

Bagozzi, R. P., \& Yi, Y. (1988). On the evaluation of structural equation models. Journal of the Academy of Marketing Science, 16(1), 74-94. doi:10.1007/BF02723327

Bamberg, S. (2003). How does environmental concern influence specific environmentally related behaviors? A new answer to an old question. Journal of Environmental Psychology, 23(1), 21-32. doi:10.1016/S0272-4944(02)00078-6

Blackwell, R. D., Miniard, P. W., \& Engel, J. F. (2001). Consumer behavior. Fort Worth, Texas: Harcourt College Publishers.

Brown, M. (2003). Buying or browsing? An exploration of shopping orientations and online purchase intention. European Journal of Marketing, 37(11/12), 1666-1684.

Cadilhon, J. (2009). Food and Agriculture Organization of the United Nations (FAO)'s Global demand of organic food, 2015. Retrieved May 7, 2018, from http://www.fao.org/docs/eims/upload/261001/Cadilhon\%202009\%20China\%20BioFach $\% 20$ presentation.pdf

Chang, M. K. (1988). Predicting unethical behavior: A comparison of the theory of reasoned action and the theory of planned behavior. Journal Business Ethics, 17(16), 1825-1834. doi:10.1007/978-94-007-4126-3_21 
Chen, M.-F. (2007). Consumer attitudes and purchase intentions in relation to organic food in Taiwan: Moderating effects of food-related personality traits. Food Quality and Preference, 18(7), 1008-1021. doi:10.1016/j.foodqual.2007.04.004

Chen, M.-F. (2009). Attitude toward organic food among Taiwanese as related to health consciousness, environmental attitudes, and the mediating effects of healthy lifestyle. British Food Journal, 111(2), 165-178. doi:10.1108/00070700910931986

Davies, A., Titterington, A. J., \& Cochrane, C. (1995). Who buys organic food? A profile of the purchasers of organic food in Northern Ireland. British Food Journal, 97(10), 17-23.

Dettmann, R. L., \& Dimitri, C. (2009) Who's buying organic vegetables? Demographic characteristics of U.S. consumers. Journal of Food Products Marketing, 16(1), 79-91. doi:10.1080/10454440903415709

Dickieson, J., Arkus, V., \& Wiertz, C. (2009). Factors that influence the purchase of organic food. A study of consumer behavior in the UK. Retrieved December 17, 2017, from https://authorzilla.com/OXKD2/factors-that-influence-the-purchase-of-organicfood.html

Ghosh, A. (1990). Retail management. Chicago, IL: Drydden Press.

Hossain, M. T. B., \& Lim, P. X. (2016). Consumers' buying behavior toward organic foods: Evidence from the emerging market. Malaysian Management Review, 51(2), 7-25.

Irianto, H. (2015). Consumers' attitude and intention towards organic food purchase: An extension of theory of planned behavior in gender perspective. International Journal of Management, Economics and Social Sciences, 4(1), 17-31.

Kalafatis, S. P., Pollard, M., East, R., \& Tsogas, M. H. (1999). Green marketing and Ajzen's theory of planned behavior: A Cross-market examination. Journal of Consumer Marketing, 16(5), 441-460. doi:10.1108/07363769910289550

Kang, H., Hahn, M., Fortin, D. R., Hyun, Y. J., \& Eom, Y. (2006). Effects of perceived behavioral control on the consumer usage intention of E-coupons. Psychology \& Marketing, 23(10), 841-864. doi:10.1002/mar.20136

Kavaliauske, M., \& Ubartaite, S. (2014). Ethical behavior influencing intention to buy organic products in Lithuania. Economics and Management, 19(1), 72-83. doi:10.5755/j01.em.19.1.4991

Keller, K. L. (2001). Building customer-based brand equity: A blueprint for creating strong brands. Marketing Science Institute, 10(2), 14-19.

Kim, D., Lee, Y., \& Lee, S. (2001). New consumer behavior. Seoul, Korea: Parkyoungsa.

Kouya, S., Sangkumchaliang, P., \& Adittoc, S. (2016). Consumers' attitude and intention to purchase organic foods in Cambodia. International Journal of Business, 21(4), 328-341.

Leong, G, Y., \& Ng, Y. L. (2014). The factors on influence consumer behavior on the purchase of organic food products(Doctoral dissertation, University of Utah). Retrieved June 17, 2018, from http://eprints.utar.edu.my/1346/1/Consumption_of_Organic_Product.pdf 
Lobo, A., Mascitelli, B., \& Chen, J. (2014). Opportunities for small and medium enterprises in the innovation and marketing of organic food: Investigating consumers' purchase behavior of organic food products in Victoria Australia. AI \& Society, 29(30), 311-322. doi:10.1007/s00146-013-0457-z

Magnusson, M. K., Arvola, A., Hursti, U.-K. K., Åberg, L., \& Sjödén, P.-O. (2001). Attitudes towards organic foods among Swedish consumers. British Food Journal, 103(3), 209227. doi:10.1108/00070700110386755

Metrscu, D. C., \& Petrescu-Mag, R. M. (2015). Organic food perception: Fad, or healthy and environmentally friendly? A case on Romania consumers. Sustainability, 7(9), 1201712031. doi:10.3390/su70912017

Ozguven, N. (2012). Organic food motivation factors for consumers. Procedia-Social and Behavioral Sciences, 62, 661-665. doi:10.1016/j.sbspro.2012.09.110

Padel, S., \& Foster, C. (2005). Exploring the gap between attitudes and behavior Understanding why consumers buy or do not buy organic food. British Food Journal, 107(8), 606-625. doi:10.1108/00070700510611002

Pomsanam, P., Napompech, K., \& Suwanmaneepong, S. (2014). Factors driving Thai consumers' intention to purchase organic foods. Asian Journal of Scientific Research, 7(4), 434-446. doi:10.3923/ajsr.2014.434.446

Radman, M. (2005). Consumer consumption and perception of organic products in Croatia. British Food Journal, 107(4), 263-273. doi:10.1108/00070700510589530

Roddy, G., Cowan, C. A., \& Hutchinson, G. (1996). Consumer attitudes and behavior of organic foods in Ireland. Journal of International Consumer Marketing, 9(2), 41-63. doi:10.1300/J046v09n02_03

Roitner-Schobesberger, B., Darnhofer, I., Somsook, S., \& Vogl, C. R. (2008). Consumer perception of organic foods in Bangkok, Thailand. Food Policy, 33(2), 112-121. doi:10.1016/j.foodpol.2007.09.004

Salleh, M. M., Ali, S. M., Jalil, M. A., \& Shaharudin, M. R. (2010). Consumers' perception and purchase intentions toward organic food products: Exploring attitude among

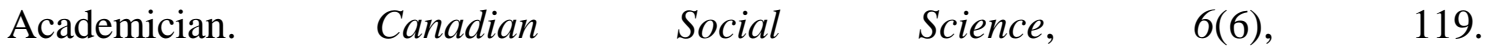
doi:10.3968/j.css.1923669720100606.013

Sangkumchaliang, P., \& Huang, W. C. (2012). Consumers' perception and attitudes of organic food products in Northern Sangkumchaliang Thailand. International Food and Agribusiness Management Review, 15(1), 87-102. doi:10.22004/AG.ECON.120860

Shafie, F. A., \& Rennie, D. (2012). Consumer perceptions towards organic food. ProcediaSocial and behavioral Sciences, 49, 360-367. doi:10.1016/j.sbspro.2012.07.034

Stobbelaar, D. J., Casimir, G., Borghuis, J., Marks, I., Meijer, L., \& Zebeda, S. (2007). Adolescents' attitudes towards organic food: A survey of 15-to 16-year old school children. International Journal of Consumer Studies, 31(4), 349-356. doi:10.1111/j.14706431.2006.00560.x 
Takayama (2017). Organic Food Industry in Vietnam. Retrieved October 20, 2017, from B \& Company World in intelligence website: http://www.bcompany.jp/en/2017/06/06/organic-food-industry-in-vietnam/

Tarkiainen, A., \& Sundqvist, S. (2005). Subjective norms, attitudes and intentions of Finnish consumers in buying organic food. British Food Journal, 107(11), 808-822.

Thalheimer, J. C. (2013). The organic Foods Debate - Are they healthier than conventional? Today's Dietitian, 15(7), 28.

Tran, T., \& Tran, V. (2016). An exploration in the theory of planned behavior: A case of organic food in Vietnam. Retrieved December 22, 2017, from https://www.researchgate.net/publication/309060874_An_exploration_in_the_theory_of _planned_behavior_A_case_of_organic_food_in_Vietnam

Tung Anh (2018). It is not easy to grow organic food in Vietnam. Retrieved December 18, 2017, from The Leader - The business leaders forum website: http://e.theleader.vn/it-is-noteasy-to-grow-organic-food-in-vietnam-20180202150716679.htm

Ueasangkomsate, P., \& Santiteerakul, S. (2016). A study of consumers' attitudes and intention to buy organic foods for sustainability. Procedia Environmental Science, 34, 423-430. doi:10.1016/j.proenv.2016.04.037

University of California, Berkeley. (1994). Pesticides in organic farming. Retrieved March 10, 2017, from Ocf.berkeley.edu

U.S. Department of Agriculture - Agricultural Marketing Service. (USDA). (2017). Understanding the USDA organic label. Retrieved May 10, 2017, from https://www.usda.gov/media/blog/2016/07/22/understanding-usda-organic-label

Vermeir, I., \& Verbeke, W. (2006). Sustainable food consumption: Exploring the consumer attitude - behavioral intention gap. Journal of Agricultural and Environmental Ethics, 19(2), 169-194. doi:10.1007/s10806-005-5485-3

Vietnamnet (2015). Organic produce popular among Vietnamese consumers despite higher prices. Retrieved December 26, 2017, from Vietnamnet website: http://english.vietnamnet.vn/fms/environment/ 146114/organic-produce-popular-amongvietnamese-consumers-despite-higher-prices.html

Voon, J. P., Ngui, K. S., \& Agrawal, A. (2011). Determinants of willingness to purchase organic food: An exploratory study using structural equation modeling. International Food and Agribusiness Management Review, 14(2), 103-120.

Wang, Y. (2014). Consumers' purchase intentions of shoes: Theory of planned behavior and desired attributes. International Journal of Marketing Studies, 6(4), 50-58. doi:10.5539/IJMS.V6N4P50

Willer, H., \& Lernoud, J. (Eds.) (2017). The world of organic agriculture. statistics and emerging trends 2017. Frick, Switzerland: Research Institute of Organic Agriculture (FiBL), Bonn, Germany: IFOAM - Organics International. 
Xie, B., Wang, L., Yang, H., Wang, Y., \& Zhang, M. (2015). Consumer perceptions and attitudes of organic food products in Eastern China. British Attitude Journal, 117(3), 1105-1121. doi:10.1108/BFJ-09-2013-0255

Yang, M., Al-Shaaban, S., \& Nguyen, T. B. (2014). Consumer attitude and purchase intention towards organic food: A quantitative study of China. (Unpublished master's thesis). Linnæus University, Sweden. Retrieved November 26, 2017, from https://www.divaportal.org/smash/get/diva2:723474/FULLTEXT01.pdf

Yin, S., Wu, L., Du, L., \& Chen, M. (2010). Consumers' purchase intention of organic food in China. Journal of the Science of Food and Agriculture, 90(8), 1361-1367. doi:10.1002/jsfa.3936

Zeithaml, V. A. (1988). Consumer perceptions of price, quality, and value: A means-end model and synthesis of evidence. Journal of Marketing, 52(3), 2-22. doi:10.1177/002224298805200302 